\title{
Difficult Airway and Pulmonary Hypertension Coexistence in a Child With I-Cell Disease
}

\author{
Zor Hava Yolu ve Pulmoner Hipertansiyon Birlikteliği olan I-Cell Hastalığı Olgusu
}

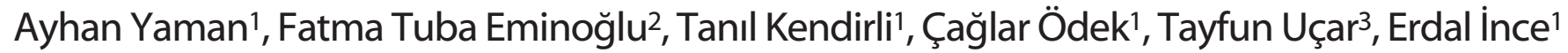

Divisions of Pediatric Intensive Care Unit, Ankara University School of
Medicine, Ankara, Turkey.
2 Pediatric Metabolism, Ankara University School of Medicine, Ankara,
Turkey.
Pediatric Cardiology, Ankara University School of Medicine, Ankara,

Pediatric Cardiology, Ankara University School of Medicine, Ankara,
Turkey.

Received : June 03,2015• Accepted: March 03,2016

Corresponding Author

Ayhan YAMAN, M.D.

Phone: +90.312.5956355/05056460378 Fax: +903123191440

E-mail: dryamanayhan@yahoo.com.tr

Ankara University School of Medicine, Division of Pediatric Intensive Care, Cebeci, 06590, Ankara, TURKEY

I-cell disease (mucolipidosis type II) is an autosomal recessive lysosomal enzyme targeting disorder leading to fatal outcome in childhood mostly due to respiratory insufficiency. The most common features of the condition are mental and physical retardation with typical orofacial features. Typical cardiac involvement includes thickening and deformation of mitral and aortic valves and dilated or hypertrophic cardiomyopathy. Mucopolysaccharidoses have been described as the worst airway problems in pediatric anesthesia, and there have been a number of previous reviews that have demonstrated a high incidence of airway problems. Here, we report the clinical course of an infant with confirmed I-cell disease (mucolipidosis type II) complicated by difficult airway and severe pulmonary hypertension, which is very rarely associated with this disorder.

Key Words: Children, Difficult Airway, I-cell Disease, Pulmonary Hypertension.

I-cell hastalığı (mukolidipoz tip 2) otozomal resesif kaltımlı, çocukluk yaș grubunda çoğunlukla solunum yetmezliğine bağlı ölümcül seyredebilen lizozomal enzim bozukluğudur. Hastalığın en sık görülen bulguları mental ve motor retardasyon ile birlikte tipik orofasiyal anomalilerdir. Tipik kardiyak bulguları mitral kapak kalınlașması, aortik kapak kalınlașması, hipertrofik ve dilate kardiyomiyopatidir. Mukopolisakkaridozlar pediatrik anestezide görülen en zor hava yolu problemleri olarak tanımlanmaktadır ve bunu teyit eden daha önce yayınlanmıs birçok yayında hava yolu problemlerinin yüksek olduğu bildirilmiștir. Bu çalıșmada I-cell hastalığı (mukolidipoz tip 2) tanısı alan, zor hava yolu ve bu hastalıkla birlikte nadir bildirilen ağır pulmoner hipertansiyonu olan bir bebek sunulmuștur.

Anahtar Sözcükler: Çocuk, I-cell hastalığı, Pulmoner hipertansiyon, Zor hava yolu.

I-cell disease (mucolipidosis type II) is an autosomal recessive, metabolic storage disorder due to a deficiency of the enzyme N-acetylglucosamine-1phosphotransferase (1). The most common features of the condition are mental and physical retardation with typical orofacial features. Infants with Icell disease are typically underweight at birth, below the 10th percentile, small, with muscle hypotonia, and coarse facial features, with the full clinical picture of the disorder presenting at between 6 and 8 months (2). Most patients die between two and eight years of age, usually of pneumonia or congestive cardiac failure $(3,4)$. The mucopolysaccharidoses (MPS) have been described as the 'worst airway problems in pediatric anesthesia' (5), and there have been a number of previous reviews that have demonstrated a high incidence of airway problems (6-8). We report herein an I-cell disease (mucolidiposis type II) case with difficult airway management and pulmonary hypertension $(\mathrm{PH})$ coexistence.

\section{Case report}

A 10 month-old male infant was admitted to our hospital's department of pediatric emergency with high temperature, respiratory distress and cyanosis problems. On physical examination, he was tachypneic, hypotonical and hypoactive. $\mathrm{He}$ appeared dysmorphic, with coarse facial features, including broad forehead, swollen eyelids, flattened nasal-root, hypertelorism, macroglossia, short neck and gingival hypertrophy (Figure 1). Respiratory system examination revealed pectus carinatum, distinct bronchospasm, prolonged expiratory phase, rhonchus and rough rales. Cardiovascular examination showed S2 rigid, 2/6 pansystolic murmur. Additionally, he had hepatomegaly, elbow and knee joint 
contractures bilaterally and had typical radiological findings of dysostosis multiplex (Figure 2). He was born as the second child of consanguineous Turkish parents. His family lost another child at 1 year of age due to pneumonia.

Physical examinaton and X-ray findings implicated a prediagnosis of I-cell disease (mucolipidosis type II). Measurements of plasma activity of almost all lysosomal hydrolases were significantly increased and the diagnosis was confirmed (Table 1).

Teleradiography revealed cardiomegaly. Echocardiographic assessment of right ventricular systolic pressure estimated from tricuspid regurgitation was initially about 70 $\mathrm{mmHg}$. Also, a small ventricular septal defect and $3 \mathrm{~mm}$ patent ductus arteriosus was noted in echocardiography. Chest computed tomography (CT) showed an

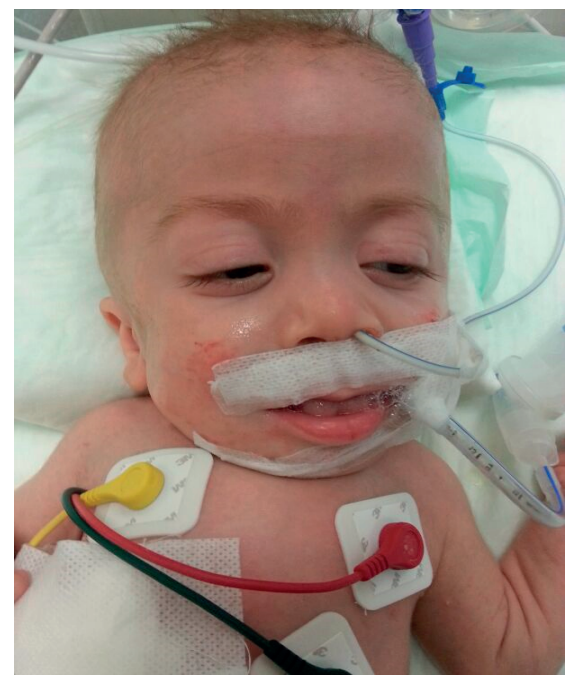

Figure.1 Typical dysostosis multiplex findings in straight bone X-Ray of patient.

Table 1 Lysosomal enzyme activities in plasma for Mucolipidosis of patient (nmol/h/ml serum).

\begin{tabular}{|l|c|c|c|}
\hline & Aryl Sulfatase A & $\alpha$-Mannosidosis & Total Hexosaminidase \\
\hline Result & 3052 & 1562 & 12039 \\
\hline Control 1 & 133 & 18 & 788 \\
\hline Control 2 & 157 & 13 & 974 \\
\hline
\end{tabular}

Figure.2 The patient's coarse facial appearance, broad forehead, swollen eyelids, nose flattened root, hypertelorism, macroglossia and short neck were present.
We had to support the high peak inspiratory pressure and positive end expiratory pressure, $36 \mathrm{cmH}_{2} \mathrm{O}$ and 13 $\mathrm{cmH}_{2} \mathrm{O}$, respectively. In the respiratory passage, viral panel Parainfluenza Type 4 was positive. Because of the patient's difficult airway, ET'T exchange using a stylet was undertaken as follows: the stylet was passed through the ETT. Then the old tube was removed and over the stylet a new tube was inserted into the airway. Correct positioning of the tube was confirmed by auscultation of the chest and by capnography. The patient could not be extubated. Tracheostomy opening was planned but the patient died on the $26^{\text {th }}$ day of his hospital admission due to respiratory failure.

\section{Discussion}

I-cell disease (mucolipidosis type II) was first described by Leroy and DeMars in 1967 (9). Diagnosis of the condition is often made in retrospect as a result of physical and mental delay. However, the presence of marked elevation of lysosomal enzymes in the plasma is an accurate diagnostic test for this disorder. Also, a diagnosis is often obtained from peripheral lymphocytes, which contain large lysosomal inclusions (10). On physical examination of our patient, the following signs and dysmorphisms were detected: coarse face, gum hyperplasia, rough voice, joint contractions and hip luxations. Dysostosis multiplex was the $\mathrm{X}$-ray finding. Measurements of plasma activity of almost all lysosomal hydrolases were significantly increased.

Pulmonary hypertension is commonly seen in depot diseases such as mucopolysaccharidosis (11). However, I-cell disease and $\mathrm{PH}$ association has only been identified in two cases in the literature $(12,13)$. A number of pulmonary complications of mucolipidosis type II have been described and include the presence of balloon cells filled with mucolipids and extracellular deposition in the connective tissue of the upper airway, congestion and focal indurations due 
to bronchopneumonia infiltrations, lipoid granuloma, and severe wall thickening of the tongue and trachea (14). In our case, interstitial lung disease as a result of stored glycoprotein might be one reason for PH. Findings of chest CT would support this hypothesis. The genesis of $\mathrm{PH}$ in patients with mucolipidosis type II might be multifactorial. Hypoxic episodes, vascular hyperreactivity, and primary cardiac symptoms of storage disease also play an important role in the genesis of $\mathrm{PH}$.

Difficult tracheal intubation occurs infrequently. Tracheal intubation of especially small infants can be challenging (15). The overall incidence of a difficult airway is 1$3 \%$ (16), but the incidence in the pediatric population is unknown (17). Risk factors for difficult tracheal reintubation include a history of previous difficult intubation, airway

\section{REFERENCES}

1. Neufeld EF, McKusick VA. Disorders of Lysosomal Enzyme Synthesis and Localization. I-cell Disease and PseudoHurler Polydystrophy. In: Stanbury JB (eds). The Metabolic Basis of Inherited Diseases. McGraw-Hill, New York, 1983; 778-787.

2. Spitz RA, Doughty RA, Spackman TJ et al. Neonatal Presentation of I-Cell Disease. Journal of Paediatrics 1978; 93: 954-958.

3. Okada S, Owada M, Sakiyama T et al. ICell Disease: Clinical Studies of 21 Japanese Cases. Clin Genet 1985; 28 : 207.

4. Satoh Y, Sakamoto K, Fujibayashi Y et al. Cardiac Involvement In Mucolipidosis: Importance Of Non-Invasive Studies For Detection Of Cardiac Abnormalities. Jpn Heart J. 1983; 24: 149.

5. Smith RM. Anaesthesia for infants and children, 4th edn. St Louis, MO: C.V. Mosby Co, 1980: 533-536.

6. Moores C, Rogers JG, McKenzie IM et al. Anaesthesia for children with mucopolysaccharidoses. Anaesth Intensive Care 1996; 24:259-463. edema secondary to surgical manipulation or volume resuscitation, morbid obesity, and an immobilized or unstable cervical spine (18). Extubation of a patient with risk factors for difficult tracheal reintubation is approached with concern, even in the experienced hands of an anesthesiologist and critical care physician. Tracheal extubation of patients at risk for difficult reintubation is frequently delayed postoperatively and often becomes the responsibility of the critical care physician. It is known that patients with mucolipidosis and mucopolysaccharidosis have restricted movement in cervical joints and macroglossia. Also, it should be kept in mind that hypertrophic nasal tissue, adenoid and tonsils lead to difficult management of the airway and intubation. A review reported an overall difficult airway rate in all MPS

7. Walker RW, Darowski M, Morris P, et al. Anaesthesia and mucopolysaccharidoses. A review of airway problems in children. Anaesthesia 1994; 49: 1078-1084.

8. Baines D, Keneally J. Anaesthetic Implications of The Mucopolysaccharidoses: A fifteen-Year Experience In A Children's Hospital. Anaesth Intensive Care 1983; 11: 198-202.

9. Leroy JG, DeMars RI. Mutant enzymatic and cytological phenotypes in cultured human fibroblasts. Science 1967; 157: 804-806.

10. Carey WF, Jauzems A, Richardson M, et al. Prenatal diagnosis of mucolipidosiselectron microscopy and biochemical evaluation. Prenatal Diagnosis 1999: 252 256.

11. Leal GN, de Paula AC, Leone C, et al. Echocardiographic study of paediatric patients with mucopolysaccharidosis. Cardiol Young. 2010; 20: 254-261.

12. Kovacevic A, Schranz D, Meissner T, et al. Mucolipidosis II complicated by severe pulmonary hypertension. Mol Genet Metab. 2011; 104: 192-193. disorders of $25 \%$ and an overall failed intubation rate of $8 \%$, but in those children with MPS I the failed intubation rate was $23 \%$ with difficulties in airway management being reported in $54 \%$ of cases (7). Our patient had a difficult airway and the patient could not be extubated. The patient's endotracheal tube exchange was done using a stylet.

In conclusion, the patient was admitted with a diagnosis of viral infection due to respiratory insufficiency. I-cell disease (mucolipidosis type II) diagnosis was made. Very little has been reported in the literature in relation to I-cell disease and pulmonary hypertension, but multifactorial reasons could play a role in its etiology. I-cell disease in patients with difficult intubation may be kept in mind. In these patients the endotracheal tube stylet can be used for the exchange.

13. Alfadhel M, AlShehhi W, Alshaalan H, A Balwi M, Eyaida W. mucolipidosis II: First report from Saudi Arabia. Ann Saudi Med. 2013; 33:382-386.

14. Ishak M, Zambrano EV, Bazzy-Asaad A, et al. Unusual pulmonary findings in mucolipidosis II. Pediatr Pulmonol. 2012; 47: 719-721.

15. Kendirli T, Ince E, Kavaz A, et al. Difficult intubation of a child through laryngeal mask airway with two tracheal tubes. Acta Paediatr. 2006; 95: 1688-1690.

16. Caplan RA, Benumof JL, Berry FA, et al: Practice guidelines for management of the difficult airway. A report by the American Society of Anesthesiologists Task Force for the management of the difficult airway. Anesthesiology 1993; 78: 597-602.

17. Kurachek SC, Newth CJ, Quasney MW, et al: Extubation failure in pediatric intensive care: A multiple-center study of risk factors and outcomes. Crit Care Med 2003; 31: 2657-2664.

18. Cooper RN. Extubation and changing endotracheal tubes. In: Benumof JL (eds). Airway Management: Principles And Practice. Mosby, Chicago, 1995; 864-883. 
